\title{
The putative mechanisms underlying testosterone and
}

\section{cardiovascular risk [version 1; peer review: 3 approved]}

\author{
Avinash Maganty, Jason R. Kovac, Ranjith Ramasamy
}

Department of Urology, Baylor College of Medicine, Houston, TX, 77030, USA

\author{
V1 First published: 04 Apr 2014, 3:87 \\ https://doi.org/10.12688/f1000research.3869.1 \\ Latest published: 04 Apr 2014, 3:87 \\ https://doi.org/10.12688/f1000research.3869.1
}

\section{Abstract}

The use of testosterone supplementation therapy (TST) is increasing primarily in men with symptomatic hypogonadism. While TST has been shown to have numerous benefits, as its use increases, the role on cardiovascular health must be explored. Previous evidence showed no adverse cardiovascular risks associated with TST use; however, more recent studies suggest that there may be an associated risk. The exact mechanism by which TST may contribute to cardiovascular risk has not been elucidated. Numerous mechanisms have been proposed which include testosterone's effect on thromboxane A2 receptors, vascular adhesion molecule 1 receptors, erythropoiesis, and obstructive sleep apnea, all of which can ultimately lead to atherogenesis and increased cardiovascular risk.

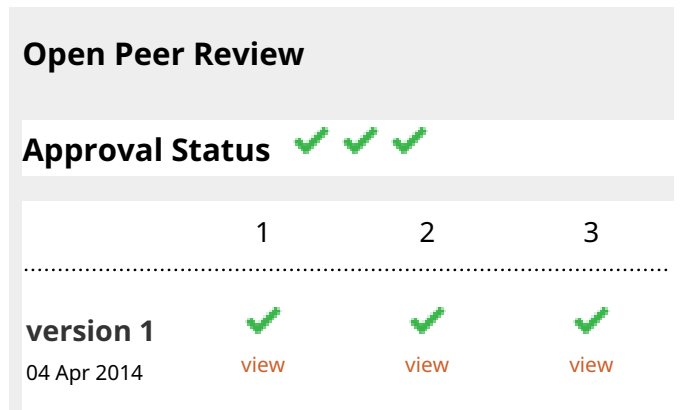

1. M. Emre Bakırcıoğlu, Bahçeci Health Group, Istanbul, Turkey

2. Matthew S. Wosnitzer, New York

Presbyterian Hospital, New York, NY, USA

3. Boback Berookhim, Memorial Sloan

Kettering Cancer Center, New York, NY, USA

Any reports and responses or comments on the article can be found at the end of the article.

Corresponding author: Ranjith Ramasamy (ranjithrama@gmail.com)

Competing interests: No competing interests were disclosed.

Grant information: The author(s) declared that no grants were involved in supporting this work.

Copyright: (c) 2014 Maganty A et al. This is an open access article distributed under the terms of the Creative Commons Attribution License, which permits unrestricted use, distribution, and reproduction in any medium, provided the original work is properly cited. Data associated with the article are available under the terms of the Creative Commons Zero "No rights reserved" data waiver (CC0 1.0 Public domain dedication).

How to cite this article: Maganty A, Kovac JR and Ramasamy R. The putative mechanisms underlying testosterone and cardiovascular risk [version 1; peer review: 3 approved] F1000Research 2014, 3:87 https://doi.org/10.12688/f1000research.3869.1

First published: 04 Apr 2014, 3:87 https://doi.org/10.12688/f1000research.3869.1 
Testosterone supplementation therapy (TST) is used to treat patients who suffer from symptomatic hypogonadism. The benefits of TST are numerous and include improved sexual function, bone mineral density, muscle mass and strength ${ }^{1}$. Currently, there is no direct evidence linking TST with cardiovascular risk factors; however, several small studies have theorized potential mechanisms (Figure 1) by which TST contributes to cardiovascular risk and these are summarized in this article.

One proposed mechanism by which cardiovascular risk could be affected is in the regulation of platelet thromboxane A2 (TXA2) receptor expression by testosterone ${ }^{2}$. TXA2, by acting on membrane receptors, helps in platelet aggregation and vascular smooth muscle contraction ${ }^{3}$. TXA2 synthesis is increased in numerous thrombotic cardiovascular events ${ }^{4}$. Ajayi et al. ${ }^{2}$ examined the relationship between testosterone and TXA2 by measuring platelet TXA2 receptor density in response to TST in healthy men ${ }^{2}$. Men were given testosterone cypionate $200 \mathrm{mg}$ IM or placebo at day 1 and day 14 of the 10-week study period. Platelet TXA2 receptor density and dissociation constant then were measured. Testosterone supplementation was associated with increased TXA2 receptor density compared with placebo, suggesting that testosterone regulates the expression of platelet TXA2 receptors. The mechanism by which this occurs is not completely understood. However, it has been shown that inhibition of both transcription and translation of TXA2 attenuates testosterone's effects on TXA2 receptor density in multiple cell lines ${ }^{5}$. This finding suggests that testosterone may increase TXA2 receptor density by acting at the genomic level to stimulate its synthesis.

Testosterone has also been shown to contribute to atherosclerotic lesions by promoting monocyte adhesion ${ }^{6}$. Atherosclerotic lesions are due to low density lipoprotein (LDL) infiltration into the arterial intima layer that subsequently results in endothelial cell activation and monocyte recruitment ${ }^{7}$. The endothelial cells express vascular cell adhesion molecule 1 (VCAM1) which allows for monocyte adhesion before transmigration through endothelial junctions? These monocytes then release local inflammatory cytokines and metalloproteinases. The inflammatory cytokines promote smooth muscle proliferation that contributes to local plaque formation. Several studies have explored the role of dihydrotestosterone (DHT), a potent testosterone metabolite, in the various aspects of atherosclerotic plaque development ${ }^{8}$. McCrohon et al. studied the effect of DHT in male umbilical vein endothelial cells9. They demonstrated increased VCAM1 expression with increased monocyte adhesion. Similar findings have been observed using arterial endothelial cells ${ }^{9}$.

Testosterone also plays a role in increasing hematocrit levels. Several studies have reported increased hematocrit levels following TST administration $^{10,11}$. This correlation is likely to be secondary to the stimulation of erythropoiesis by testosterone. Increased hematocrit levels, or polycythemia, can itself contribute to adverse cardiovascular events. For example, an increased number of red blood cells can result in increased blood viscosity and predispose to thrombosis. A recent study by Marchioloi et al. analyzed the cardiovascular risks in patients with polycythemia vera ${ }^{12}$. Patients, whose mean age was 64 (62\% males), were divided into either a less intensive treatment group in which the target hematocrit was $45-50 \%$ or an intensive treatment group in which the target hematocrit was $45-50 \%$. The choice of therapeutic approach was left to the investigator. The primary endpoint studied was the time until death from a cardiovascular cause or a major thrombotic event. The authors found that those whose hematocrit was maintained below $45 \%$ had significantly lower rate of cardiovascular death and major thrombotic events compared to those who had a hematocrit between $45-50 \%{ }^{12}$. Additionally, Kunnas et al. evaluated the association between hematocrit and coronary heart disease (CHD) in men over 55 $5^{13}$. This study's conclusions were similar to that previously discussed, in that men with a hematocrit greater than $50 \%$ were 1.8 times (1.1-2.7) more likely to die from CHD compared with men with a hematocrit of less than $50 \%$ after adjusting for coronary risk factors ${ }^{13}$.

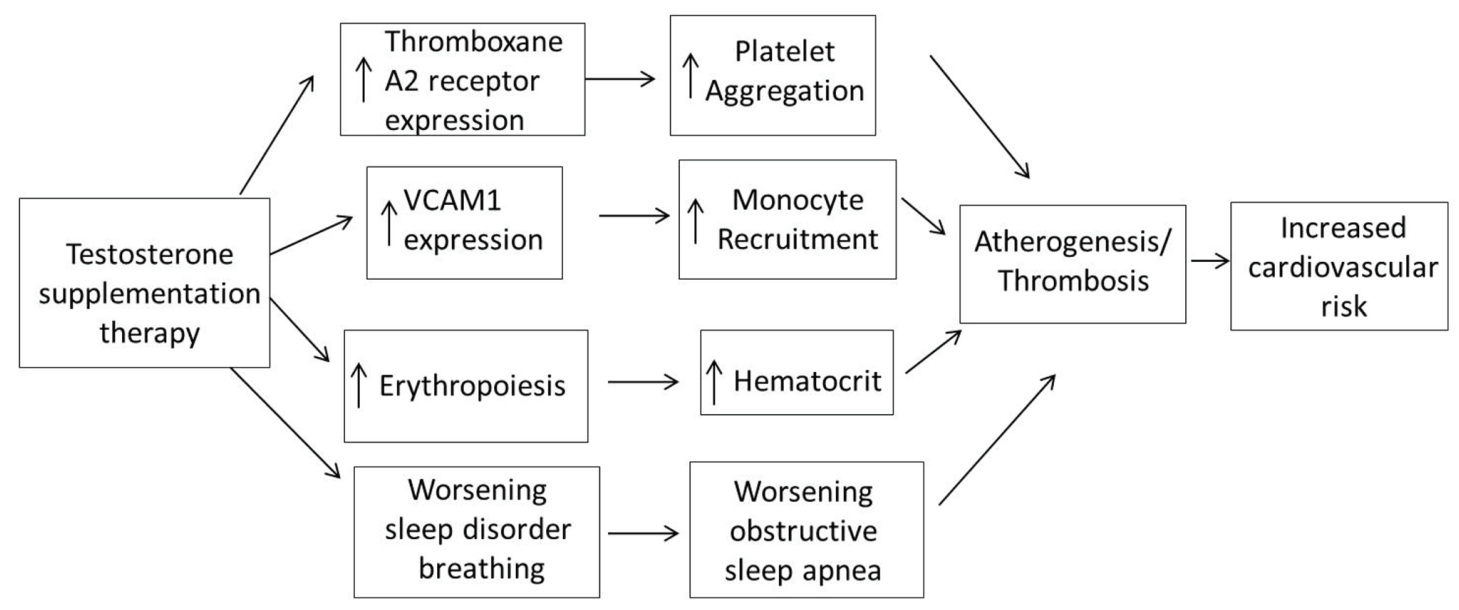

Figure 1. Proposed schematic by which TST may contribute to cardiovascular risk. TST increases TXA2 receptor expression, VCAM1 expression, erythropoiesis, and worsens sleep disorder breathing, all of which ultimately contribute to atherogenesis and worsening of cardiovascular health. VCAM1 - vascular cell adhesion molecule 1. 
Testosterone may also contribute to cardiovascular disease by worsening pre-existing obstructive sleep apnea (OSA). Androgen deficiency is often observed in men who are obese or who have $\mathrm{OSA}^{14-16}$. Obese men have lower serum testosterone compared to age-matched non-obese men ${ }^{17}$. This may be secondary to hypothalamic dysfunction or increased metabolic clearance as a result of central obesity ${ }^{17}$. Similarly, previous studies have shown that men with OSA have low systemic testosterone levels, independent of increasing age or obesity, that correlate with the severity of hypoxia during sleeping hours $^{16,18,19}$. Additionally, the low systemic testosterone levels in these men have been shown to be reversible with nasal continuous positive airways pressure therapy $(\mathrm{CPAP})^{16,19}$. The mechanism of reduced testosterone in men with OSA is likely to occur through OSA mediated dysfunction of the pituitarygonadal axis ${ }^{17,20}$. Although controversial, TST has been used in men with severe OSA, given that men may remain androgen deficient if they are unable to comply with continuous positive airway pressure (CPAP) or lose weight ${ }^{21}$. Hoyos et al. studied the effects of TST by conducting a randomized, double-blind, placebo controlled trial in 67 men with severe OSA. Testosterone treatment worsened the oxygen desaturation index and nocturnal hypoxemia compared to placebo, suggesting worsening of OSA ${ }^{14}$. OSA itself is an independent risk factor for cardiovascular disease, and is associated with myocardial infarction and stroke ${ }^{22}$. OSA likely contributes to disease by worsening atherosclerosis by affecting multiple atherogenic pathways such as hypertension, insulin resistance, dyslipidemia, endothelial dysfunction, and oxidative stress ${ }^{22}$.

While testosterone has not been definitively linked to cardiovascular risk, these proposed mechanisms provide some insights into TST's physiological effect on the cardiovascular system. Despite recent studies demonstrating an increased cardiovascular risk associated with $\mathrm{TST}^{23}$, there is a large body of literature demonstrating the benefits of testosterone therapy. In fact testosterone replacement has demonstrated to decrease mortality ${ }^{24,25}$. Until the results of randomized trials are available, appropriate patient counseling and an emphasis on the importance of compliance with follow-up are essential prior to initiating testosterone replacement.

\section{Author contributions}

All the authors contributed equally to the writing of the manuscript.

\section{Competing interests}

No competing interests were disclosed.

\section{Grant information}

The author(s) declared that no grants were involved in supporting this work.

\section{References}

1. Vigen R, O'Donnell Cl, Barón AE, et al:: Association of testosterone therapy with mortality, myocardial infarction, and stroke in men with low testosterone levels. JAMA. 2013: 310(17): 1829-36.

PubMed Abstract | Publisher Full Text

2. Ajayi AA, Mathur R, Halushka PV: Testosterone increases human platelet thromboxane $A 2$ receptor density and aggregation responses.

Circulation. 1995; 91(11): 2742-7.

PubMed Abstract | Publisher Full Text

3. Halushka PV, Mais DE, Mayeux PR, et al:: Thromboxane, prostaglandin and leukotriene receptors. Annu Rev Pharmacol Toxicol. 1989; 29: 213-39. PubMed Abstract | Publisher Full Text

4. Fitzgerald DJ, Roy L, Catella F, et al.: Platelet activation in unstable coronary disease. N Engl J Med. 1986; 315(16): 983-9. PubMed Abstract | Publisher Full Text

5. Matsuda K, Mathur RS, Duzic E, et al:: Androgen regulation of thromboxane A2/prostaglandin $\mathrm{H} 2$ receptor expression in human erythroleukemia cells. Am J Physiol. 1993; 265(6 Pt 1): E928-E34. PubMed Abstract

6. McCrohon JA, Jessup W, Handelsman DJ, et al:: Androgen exposure increases human monocyte adhesion to vascular endothelium and endothelial cell expression of vascular cell adhesion molecule-1. Circulation. 1999; 99(17): 2317-22.

PubMed Abstract | Publisher Full Text

7. Hansson GK: Inflammation, atherosclerosis, and coronary atery disease. N Engl J Med. 2005; 352(16): 1685-95. PubMed Abstract | Publisher Full Text

8. Death AK, McGrath KC, Sader MA, et al.: Dihydrotestosterone promotes vascular cell adhesion molecule-1 expression in male human endothelial cells via a nuclear factor-kappaB-dependent pathway. Endocrinology. 2004; 145(4): 1889-97. PubMed Abstract | Publisher Full Text

9. McCrohon JA, Jessup W, Handelsman DJ, et al:: Androgen exposure increases human monocyte adhesion to vascular endothelium and endothelial cell expression of vascular cell adhesion molecule-1. Circulation. 1999; 99(17): 2317-22.

PubMed Abstract | Publisher Full Text

10. Haddad RM, Kennedy CC, Caples SM, et al:: Testosterone and cardiovascular risk in: a systematic review and meta-analysis of randomized placebo-controlled trials. Mayo Clin Proc. 2007; 82(1): 29-39. PubMed Abstract | Publisher Full Text

11. Basaria S, Coviello AD, Travison TG, et al.: Adverse events associated with testosterone administration. N Engl J Med. 2010; 363(2): 109-22. PubMed Abstract | Publisher Full Text | Free Full Text

12. Marchioli R, Finazzi G, Specchia G, et al:: Cardiovascular events and intensity of treatment in polycythemia vera. N Engl J Med. 2013; 368(1): 22-33. PubMed Abstract | Publisher Full Text

13. Kunnas T, Solakivi T, Huuskonen $\mathrm{K}$, et al:: Hematocrit and the risk of coronary heart disease mortality in the TAMRISK study, a 28-year follow-up. Prev Med. 2009; 49(1): 45-7.

PubMed Abstract | Publisher Full Text

14. Hoyos CM, Killick R, Yee BJ, et al.: Effects of testosterone therapy on sleep and breathing in obese men with severe obstructive sleep apnea: a randomized placebo-controlled trial. Clin Endocrinol (Oxf). 2012; 77(4): 599-607. PubMed Abstract | Publisher Full Text

15. Wu FCW, Tajar A, Beynon JM, et al.: Identification of late-onset hypogonadism in middle-aged and elderly men. N Engl J Med. 2010; 363(2): 123-35. PubMed Abstract | Publisher Full Text

16. Grunstein RR, Handelsman DJ, Lawrence SJ, et al.: Neuroendocrine dysfunction in sleep apnea: reversal by continuous positive airways pressure therapy. J Clin Endocrinol Metab. 1989; 68(2): 352-8. PubMed Abstract | Publisher Full Text

17. Liu PY, Caterson ID, Grunstein RR, et al.: Androgens, obesity, and sleepdisordered breathing in men. Endocrinol Metab Clin North Am. 2007; 36(2): 349-63.

PubMed Abstract | Publisher Full Text

18. Gambineri A, Pelusi C, Pasquali R: Testosterone levels in obese male patients with obstructive sleep apnea syndrome: relation to oxygen desaturation, body weight, fat distribution, and metabolic parameters. J Endocrinol Invest. 2003; 26(6): 493-8. PubMed Abstract

19. Meston N, Davies RJ, Mullins R, et al:: Endocrine effects of nasal continuous positive airway pressure in male patients with obstructive sleep apnoea. J Intern Med. 2003; 254(5): 447-54. PubMed Abstract | Publisher Full Text

20. Luboshitzky R, Aviv A, Hefetz A, et al.: Decreased pituitary-gonadal secretion in men with obstructive sleep apnea. J Clin Endocrinol Metab. 2002; 87(7): 3394-8. PubMed Abstract | Publisher Full Text

21. Bhasin S, Cunningham GR, Hayes FJ, et al.: Testosterone therapy in men with androgen deficiency syndromes: an Endocrine Society clinical practice 
guideline. J Clin Endocrinol Metab. 2010; 95(6): 2536-59. PubMed Abstract | Publisher Full Text

22. Drager LF, Polotsky VY, Lorenzi-Filho G: Obstructive sleep apnea: An emerging risk factor for atherosclerosis. Chest. 2011; 140(2): 534-42.

PubMed Abstract | Publisher Full Text | Free Full Text

23. Finkle WD, Greenland S, Ridgeway GK, et al.: Increased risk of non-fatal myocardial infarction following testosterone therapy prescription in men PLoS One. 2014;9(1): e85805.

PubMed Abstract | Publisher Full Text | Free Full Text
24. Muraleedharan $\mathrm{V}$, Marsh $\mathrm{H}$, Kapoor D, et al:: Testosterone deficiency is associated with increased risk of mortality and testosterone replacement improves survival in men with type 2 diabetes. Eur J Endocrinol. 2013;

169(6): 725-33.

PubMed Abstract | Publisher Full Text

25. Shores MM, Smith NL, Forsberg CW, et al:: Testosterone treatment and mortality in men with low testosterone levels. J Clin Endocrinol Metab. 2012; 97(6): 2050-8. PubMed Abstract | Publisher Full Text 


\section{Open Peer Review}

\section{Current Peer Review Status:}

\section{Version 1}

Reviewer Report 22 April 2014

https://doi.org/10.5256/f1000research.4144.r4380

(C) 2014 Berookhim B. This is an open access peer review report distributed under the terms of the Creative Commons Attribution License, which permits unrestricted use, distribution, and reproduction in any medium, provided the original work is properly cited.

\section{Boback Berookhim}

Memorial Sloan Kettering Cancer Center, New York, NY, USA

Maganty and colleagues provide a timely and interesting report on a rather controversial topic which has been the subject of a number of recent, large, population-based, retrospective studies that have received media attention. The role of testosterone replacement therapy in worsening cardiovascular disease remains unanswered, and will likely require extensive, well-matched, randomized, placebo-controlled trials to prove its effect - whether protective, or aggravating - in cardiovascular disease.

The authors, however, provide a well researched review of the putative mechanisms underlying this possible, though unproven, relationship. While the thromboxane $A 2$, monocyte activation, polycythemia vera and obstructive sleep apnea pathways proposed are plausible, there is - to date - no clear evidence that any of these contribute to increased cardiovascular risk in men. Platelet activation and increasing atherosclerotic intimal plaque would be interesting topics for further research in testosterone replacement therapy, and will help to better elucidate this issue.

Competing Interests: No competing interests were disclosed.

I confirm that I have read this submission and believe that I have an appropriate level of expertise to confirm that it is of an acceptable scientific standard.

Reviewer Report 15 April 2014

https://doi.org/10.5256/f1000research.4144.r4378

(C) 2014 Wosnitzer $\mathbf{M}$. This is an open access peer review report distributed under the terms of the Creative Commons Attribution License, which permits unrestricted use, distribution, and reproduction in any medium, provided the original work is properly cited. 


\section{Matthew S. Wosnitzer}

Department of Urology, New York Presbyterian Hospital, New York, NY, USA

This is a comprehensive summary of the potential mechanisms (i.e. platelet thromboxane A2 receptor, monocyte adhesion via endothelial cell vascular cell adhesion molecule 1, increased hematocrit level) underlying the possible association of testosterone supplementation therapy (TST) with cardiovascular outcomes. The discussion of possible mechanisms is important in light of recent questions about the cardiovascular side effects of TST, with studies showing both decreased and increased cardiovascular and mortality risk. An ideal study would be prospective and include additional measurements of hematocrit (or TXA2, VCAM1 for example) which could be related to cardiovascular outcomes and help to better select which men may derive the most benefit and least risk from TST.

Additionally, a recent by Yassin et al. ${ }^{1}$ adds more data for the safety of TST (intramuscular testosterone undecanoate) in older men with late-onset hypogonadism and erectile dysfunction (mean age 59 years with mean treatment duration of over 4 years). No cardiovascular side effects were noted during the study and there was improvement of metabolic syndrome-related characteristics including obesity, blood glucose, cholesterol, and BP. Subjects were mostly were overweight or obese, and a minority had baseline cardiovascular comorbidities (12\%), DM2 (31\%) or HTN $(45 \%)$ issues (which are similar to - or increased compared with - the baseline characteristics of the Finkle et al. study ${ }^{2}$ - reference 23 in the article). In the future, more studies are needed to confirm these findings, especially investigating the mechanisms by which TST may affect cardiovascular outcomes.

\section{References}

1. Yassin DJ, Doros G, Hammerer PG, Yassin AA: Long-Term Testosterone Treatment in Elderly Men with Hypogonadism and Erectile Dysfunction Reduces Obesity Parameters and Improves Metabolic Syndrome and Health-Related Quality of Life.J Sex Med.2014. PubMed Abstract I Publisher Full Text

2. Finkle WD, Greenland S, Ridgeway GK, Adams JL, et al.: Increased risk of non-fatal myocardial infarction following testosterone therapy prescription in men.PLoS One.2014; 9 (1): e85805 PubMed Abstract | Free Full Text | Publisher Full Text

Competing Interests: No competing interests were disclosed.

\section{I confirm that I have read this submission and believe that I have an appropriate level of} expertise to confirm that it is of an acceptable scientific standard.

Reviewer Report 15 April 2014

https://doi.org/10.5256/f1000research.4144.r4383

(C) 2014 Bakırcıoğlu M. This is an open access peer review report distributed under the terms of the Creative Commons Attribution License, which permits unrestricted use, distribution, and reproduction in any medium, provided the original work is properly cited. 


\section{Emre Bakırcıoğlu}

Fulya IVF Center, Bahçeci Health Group, Istanbul, Turkey

This manuscript - 'The putative mechanisms underlying testosterone and cardiovascular risk' - gives valuable information about the mechanisms of cardiovascular effects of testosterone supplementation therapy in hypogonadal men. This opinion article is well written and deserving of indexation.

Competing Interests: No competing interests were disclosed.

I confirm that I have read this submission and believe that I have an appropriate level of expertise to confirm that it is of an acceptable scientific standard.

The benefits of publishing with F1000Research:

- Your article is published within days, with no editorial bias

- You can publish traditional articles, null/negative results, case reports, data notes and more

- The peer review process is transparent and collaborative

- Your article is indexed in PubMed after passing peer review

- Dedicated customer support at every stage

For pre-submission enquiries, contact research@f1000.com 